\title{
Arsenic and Other Elemental Concentrations in Mushrooms from Bangladesh: Health Risks
}

\author{
Md Harunur Rashid ${ }^{1,2,3}$, Mohammad Mahmudur Rahman ${ }^{1,2}{ }^{(0)}$, Ray Correll ${ }^{4}$ and \\ Ravi Naidu 1,2,* \\ 1 Global Centre for Environmental Remediation (GCER), The University of Newcastle, University Drive, \\ Callaghan, NSW 2308, Australia; mdharunur.rashid@uon.edu.au (M.H.R.); \\ mahmud.rahman@newcastle.edu.au (M.M.R.) \\ 2 Cooperative Research Centre for Contamination Assessment and Remediation of the \\ Environment (CRC-CARE), Callaghan, NSW 2308, Australia \\ 3 Soil Science Division, Bangladesh Agricultural Research Institution (BARI), Joydebpur, Gazipur 1701, \\ Bangladesh \\ 4 Rho Environmetrics, Highgate, SA 5063, Australia; rho.environmetrics@bigpond.com \\ * Correspondence: ravi.naidu@newcastle.edu.au; Tel.: +61-2491-38705
}

Received: 9 April 2018; Accepted: 3 May 2018; Published: 4 May 2018

\begin{abstract}
Mushroom cultivation has been increasing rapidly in Bangladesh. Arsenic (As) toxicity is widespread in the world and Bangladesh faces the greatest havoc due to this calamity. Rice is the staple food in Bangladesh and among all the crops grown, it is considered to be the main cause of As poisoning to its population after drinking water. Consequently, rice straw, an important growing medium of mushrooms in Bangladesh, is known to have high As content. The objective of this study was, therefore, to determine the concentrations of As in mushrooms cultivated in Bangladesh and to assess the health risk as well. It also considered other elements, including $\mathrm{Cd}, \mathrm{Cr}, \mathrm{Co}, \mathrm{Cu}, \mathrm{Pb}, \mathrm{Mn}$, $\mathrm{Hg}, \mathrm{Ni}$, and $\mathrm{Zn}$ concentrations in mushrooms from Bangladesh. The mean concentrations $(\mathrm{mg} / \mathrm{kg})$ of $\mathrm{As}, \mathrm{Cd}, \mathrm{Cr}, \mathrm{Co}, \mathrm{Cu}, \mathrm{Pb}, \mathrm{Mn}, \mathrm{Hg}, \mathrm{Ni}$, and $\mathrm{Zn}$ in mushrooms were $0.51,0.38,0.28,0.01,13.7,0.31$, $11.7,0.12,0.28$, and 53.5 , respectively. Based on the dietary intake of mushrooms, the weekly intakes of As, Cd, Cr, Co, Cu, Pb, Mn, Hg, Ni, and $\mathrm{Zn}$ from mushrooms for adults were 0.0042, 0.0030, $0.0024,0.0001,0.1125,0.0019,0.1116,0.0011,0.0023$, and $0.4734 \mathrm{mg}$, respectively. Due to the low concentrations of As and other trace elements observed in mushrooms from Bangladesh, as well as relatively lower consumption of this food in people's diet, it can be inferred that consumption of the species of mushrooms analysed will cause no toxicological risk.
\end{abstract}

Keywords: mushroom; arsenic; heavy metals; health risk; daily intake

\section{Introduction}

Geogenic arsenic (As) contamination in groundwater occurs in more than 107 countries worldwide [1]. About 100 million people of Bangladesh and the state West Bengal of India together [2], and more than 296 million of the global population in total [1], are at risk of As poisoning. In As-prone areas, many people suffer from skin disorders, respiratory, nervous, obstetric system disorders, diabetes, cardiovascular diseases, as well as cancers of various organs, such as skin, kidney, liver, bladder, etc. [2]. Bangladesh is a densely-populated country and to cope with the demand of the burgeoning population, it has intensified rice production especially during the dry season, which provides higher a yield than rice varieties cultivated in the wet season. The dry season rice requires large amounts of irrigation water that reach as high as 11,500 $\mathrm{m}^{3} /$ ha [3], mostly extracted from groundwater through shallow tube-wells. Unfortunately, elevated levels of naturally-originated 
As have been detected in groundwater of Bangladesh [4] and the As-contaminated groundwater is extensively used for irrigating crops, especially paddy rice. A study estimated that irrigation with As-contaminated groundwater introduced 1360 tons of As into paddy soil each year in Bangladesh [5], although the mass balance and fate of the introduced As in agricultural soils is yet to be determined. Rice grown in As-contaminated soil and irrigation water increase As concentration in rice grain, shoos, and straw, which are primarily used as human food and cattle feed [6]. The concentration of As exceeded the World Health Organization (WHO) guideline value $(10 \mu \mathrm{g} / \mathrm{L})$ for drinking water in $42 \%$ of the 52,202 tube wells in the contaminated regions [4]. Concentrations of other elements, such as $\mathrm{Mn}, \mathrm{Cr}, \mathrm{Pb}$, and $\mathrm{Ni}$ also exceeded the $\mathrm{WHO}$ health-based drinking water guideline values in the groundwater of Bangladesh [7].

Mushrooms are heterotrophic eukaryotic organisms classified in the kingdom of fungi. There are about 5.1 million fungal species in the world [8]. Over 75,000 species of fungi exist in the European continent, of which over 15,000 species are macro fungi (fungi that form fruiting bodies or sporocarps) which are visible to the naked eye [9]. The fruiting body bears spores is the morphological part of the fungus that is commonly called mushroom. More than 2000 mushroom species prevail in nature, of which only about 22 species are cultivable [10]. They have been an important part of diet in many countries [11], especially the cultivated ones, such as Agaricus spp., Pleurotus spp., Lentinus edodes, Volvariella volvacea, and Auricularia spp. [12]. Across the world mushroom cultivation is now a multi-billion dollar business [13]. Commercial mushroom cultivation was initiated by the Bangladesh Agricultural Research Council in Mushroom Culture Centre at Savar, Dhaka in early 1980s [14] as Bangladesh is one of the most suitable countries for mushroom cultivation due to its tropical monsoon type climate and low production cost. Apart from Savar, mushroom cultivation has been booming near the capital and other districts of Bangladesh. In the last 20 years, mushroom consumption and production have increased at a faster rate than almost any other agricultural food products. Rice straw and sawdust are usually used as media to cultivate mushrooms in Bangladesh; of course, wheat straw, gypsum, oak and beech sawdust or chicken manure are also used as typical substrates for mushroom cultivation in many parts of the world [15-17].

The literature demonstrates that any of the substrates, if collected from polluted areas, can facilitate higher accumulation of trace elements, particularly As and $\mathrm{Hg}[18,19]$. One study revealed that As concentration in rice straw increased significantly (from $3.9 \mathrm{mg} / \mathrm{kg}$ to $91.8 \mathrm{mg} / \mathrm{kg}$ ) with increasing As concentration in irrigation water (up to $8.0 \mathrm{mg} / \mathrm{L}$ of As) [6]. In As-contaminated areas, rice straw has been found to contain $1.15 \mathrm{mg} / \mathrm{kg}$ of As [20]. Various investigations have dealt with metal concentrations of mushrooms, especially edible ones, and many edible mushroom species are known to accumulate high levels of heavy metals [21]. However, there have not been any previous studies focused on the concentrations of As and other toxic elements in edible mushrooms grown in Bangladesh. This study reports concentrations of As and other elements in edible mushrooms available near Dhaka City, Bangladesh. We use those data to assess whether mushroom consumption poses any health risks to humans, given that $\mathrm{As}, \mathrm{Cr}, \mathrm{Cd}, \mathrm{Pb}$, and $\mathrm{Hg}$ are highly toxic and the exposure route is often through food.

\section{Materials and Methods}

\subsection{Mushroom Cultivation and Consumption in Bangladesh}

There is no information available on daily consumption of mushroom/person in Bangladesh. In Bangladesh, mushroom production and consumption is limited to urban and semi-urban areas. Mushrooms are consumed by $77 \%$ of higher-income groups and by $37 \%$ of medium-income groups [22]. Before the 1970s, mushrooms were usually consumed by some of the tribes as per their custom, but now the situation has changed due to mushrooms' agreeable aroma, excellent subtle flavour and, above all, their nutritional and medicinal values. Many exotic food preparations, such as soup, vegetables, pickles, etc., are made from mushrooms, and have become highly popular for about $58 \%$ of customers 
in Bangladesh [22]. According to the most recent database, about 620-675 tons of fresh mushrooms is produced in Bangladesh per annum [23], thus, the mushroom consumption rate is estimated as $0.09 \mathrm{~g}$ (fresh weight) weekly, considering 675 tons of mushroom production per annum and the total population for that time was 140.6 million [23]. Data from the wholefood catalog [24] indicates that the dry matter content of the mushrooms averages $13 \%$, giving an average weekly intake on a dry matter basis of $0.01 \mathrm{~g}$. Generally mushrooms from three genera, namely Pleurotus, Agaricus, and Calocybe are cultivated in Bangladesh at the rate of $97 \%, 1 \%$, and $1 \%$, respectively [23] and they are commonly called Oyster, Button, and Milki mushrooms, respectively. The additional $1 \%$ of mushrooms are mainly Volvariella spp. and Auricularia spp. It was also reported that among the P. spp., $61 \%$ were P. ostreatus, followed by $19 \%$ P. sajorcaju, 12\% P. florida, and 8\% of P. high king-51 [23]. At the time of collecting fresh edible mushrooms for the present study from the Mushroom Development and Extension Institute, Savar (on the outskirts of the capital, Dhaka) and a commercial farm of Gazipur (about $10 \mathrm{~km}$ from the main city), only P. ostreatus and P. high-king were in the production phase.

\subsection{Sampling, Sample Processing, Digestion and Analysis}

Fresh edible mushrooms ( $P$. high-king and P. ostreatus; $n=2 \times 20$ ) with respective growing media (rice straw; $n=2 \times 20$ ) were collected from the "Mushroom development and Extension Institute" Savar, Dhaka, and the same from a private mushroom farm at Gazipur during 2014. Some commercially-available powdered mushroom samples (Pleurotus sp.; $n=5$ ) were also purchased from local markets in Dhaka and Gazipur.

The substrate debris and stalks of the mushroom samples were removed with a disposable plastic knife. The mushroom samples were then washed in running tap water (three times) to remove the debris followed by washing three times with deionised water. The washed samples were then air dried for approximately $48 \mathrm{~h}$ at $20^{\circ} \mathrm{C}$ and then placed in an oven for drying at $60{ }^{\circ} \mathrm{C}$. The dried samples were then homogenized and ground. A similar procedure was also employed for the processing of growing media.

\subsection{Sample Preparation}

A microwave digestion system with 40 rotors (model: MARS 6, CEM Corporation, Matthews, NC, USA) was used for the digestion of the samples. Trace grade concentrated nitric acid (Fisher Chemicals, Hampton, NH, USA) was used for the digestion of mushroom. The As speciation study was conducted after extracting samples with $2 \mathrm{M}$ trifluoroacetic acid (TFA) as per standard procedure [6].

\subsection{Sample Analysis}

An Agilent 7500ce (Agilent Technologies, Tokyo, Japan) inductively-coupled plasma mass spectrometer (ICP-MS) was used to determine the amount of As and other elements in mushrooms and rice straw. An Agilent liquid chromatography system (1100 series, Agilent Technologies, Tokyo, Japan) was used for As speciation study. A Hamilton PRPX-100 along with a guard column coupled with ICP-MS was used to measure As species (As(III), As(V)), MMA(V), and DMA(V) in mushroom. The elemental concentration of samples was determined on a dry weight basis.

\subsection{Quality Control: Analysis of Standard Reference Material (SRM)}

Standard reference material (SRM) from the National Institute of Standards and Technology (NIST), such as 1573a (tomato leaves), were analysed for As and other elements utilizing the same procedure as that used for mushroom and rice straw samples to check the effectiveness of the digestion and analytical procedure. 


\subsection{Health Risk Index (HRI)}

The health risk index was measured as the ratio of estimated exposure of mushroom and oral reference dose [25]. Estimated exposure was obtained by dividing weekly intake of elements by their safe limits or oral reference dose. An index of more than 1.0 was considered unsafe for human health [26].

The weekly intake of elements $\left(\mathrm{WI}_{\mathrm{E}}\right)$ was calculated by using the following equation:

$$
\mathrm{WI}_{\mathrm{E}}=\mathrm{C}_{\mathrm{E}} \times \mathrm{W}_{\mathrm{MI}} / \mathrm{B}_{\mathrm{AW}},
$$

where $C_{E}, W_{M I}$, and $B_{A W}$ represent the elemental concentrations in mushrooms $(\mathrm{mg} / \mathrm{kg})$, weekly intake of mushrooms, and average body weight $(45 \mathrm{~kg})$ of adults in Bangladesh [27].

\subsection{Statistical Analysis}

All the statistical analyses were carried out using R software [28]. The data on arsenic and heavy metals concentration in mushrooms were analysed using analysis of variance (ANOVA) using the 'aov' command. The residual sum of squares was then used for calculating Fisher's protected least significant differences. The accumulation factors were assessed as the ratio of the concentration in the mushroom divided by the concentration in the medium. Correlations between concentration in the medium and concentration in the mushroom were performed using the 'cor' function in R. Principal component analyses were performed using the 'princomp' command in $\mathrm{R}$ and were based on the correlation matrix.

\section{Results and Discussion}

Table 1 shows the concentration of As and other trace elements in mushrooms under investigation. It also demonstrates the percent recovery of analytical results where we noticed about $88-112 \%$ recovery using tomato leaves (NIST SRM). Figure 1 demonstrates that As levels were higher $(p<0.001)$ at Savar $(0.62 \mathrm{mg} / \mathrm{kg})$ than at Gazipur $(0.38 \mathrm{mg} / \mathrm{kg})$ and at Savar As in P. high-king $(0.76 \mathrm{mg} / \mathrm{kg})$ was higher $(p<0.05)$ than the level in P. ostreatus $(0.49 \mathrm{mg} / \mathrm{kg})$. Cd showed the opposite trend with Cd being higher $(p<0.001)$ at Gazipur $(0.49 \mathrm{mg} / \mathrm{kg})$ than at Savar $(0.28 \mathrm{mg} / \mathrm{kg})$ where P. ostreatus $(0.34 \mathrm{mg} / \mathrm{kg})$ was higher $(p<0.05)$ than $P$. high-king $(0.22 \mathrm{mg} / \mathrm{kg})$. Mercury was higher $(p<0.001)$ at Savar $(0.15 \mathrm{mg} / \mathrm{kg})$ than at Gazipur $(0.11 \mathrm{mg} / \mathrm{kg})$. Concentration of $\mathrm{Pb}$ in P. high-king $(0.40 \mathrm{mg} / \mathrm{kg})$ was almost double than that of P. ostreatus $(0.22 \mathrm{mg} / \mathrm{kg})$ and the difference was significant $(p<0.05)$. The other elemental differences between the species were not statistically significant. The order of the median concentrations $(\mathrm{mg} / \mathrm{kg}$ ) of elements in mushrooms was found to be as $\mathrm{Zn}>\mathrm{Cu}>\mathrm{Mn}>\mathrm{As}>$ $\mathrm{Cd}>\mathrm{Pb}>\mathrm{Cr}>\mathrm{Ni}>\mathrm{Hg}>\mathrm{Co}$ with value of 50.4, 12.5, 12.2, 0.49, 0.30, 0.23, 0.22, 0.22, 0.12, and 0.01, respectively, for P. high-king. On the other hand in case of $P$. ostreatus the concentrations $(\mathrm{mg} / \mathrm{kg})$ were $54.8,12.7,12.6,0.45,0.38,0.31,0.29,0.19,0.12$, and 0.01 for those elements that follows the order of $\mathrm{Zn}$ $>\mathrm{Mn}>\mathrm{Cu}>\mathrm{As}>\mathrm{Cd}>\mathrm{Cr}>\mathrm{Ni}>\mathrm{Pb}>\mathrm{Hg}>\mathrm{Co}$, respectively.

The elemental concentrations of cultivated mushrooms in this study were compared to research findings on cultivated mushrooms by various researchers around the world (Table 2) though available data on cultivated mushrooms are less $[29,30]$ as compared to wild ones. Reported results showed that elemental concentrations in the mushrooms varied widely depending on locations and species. 


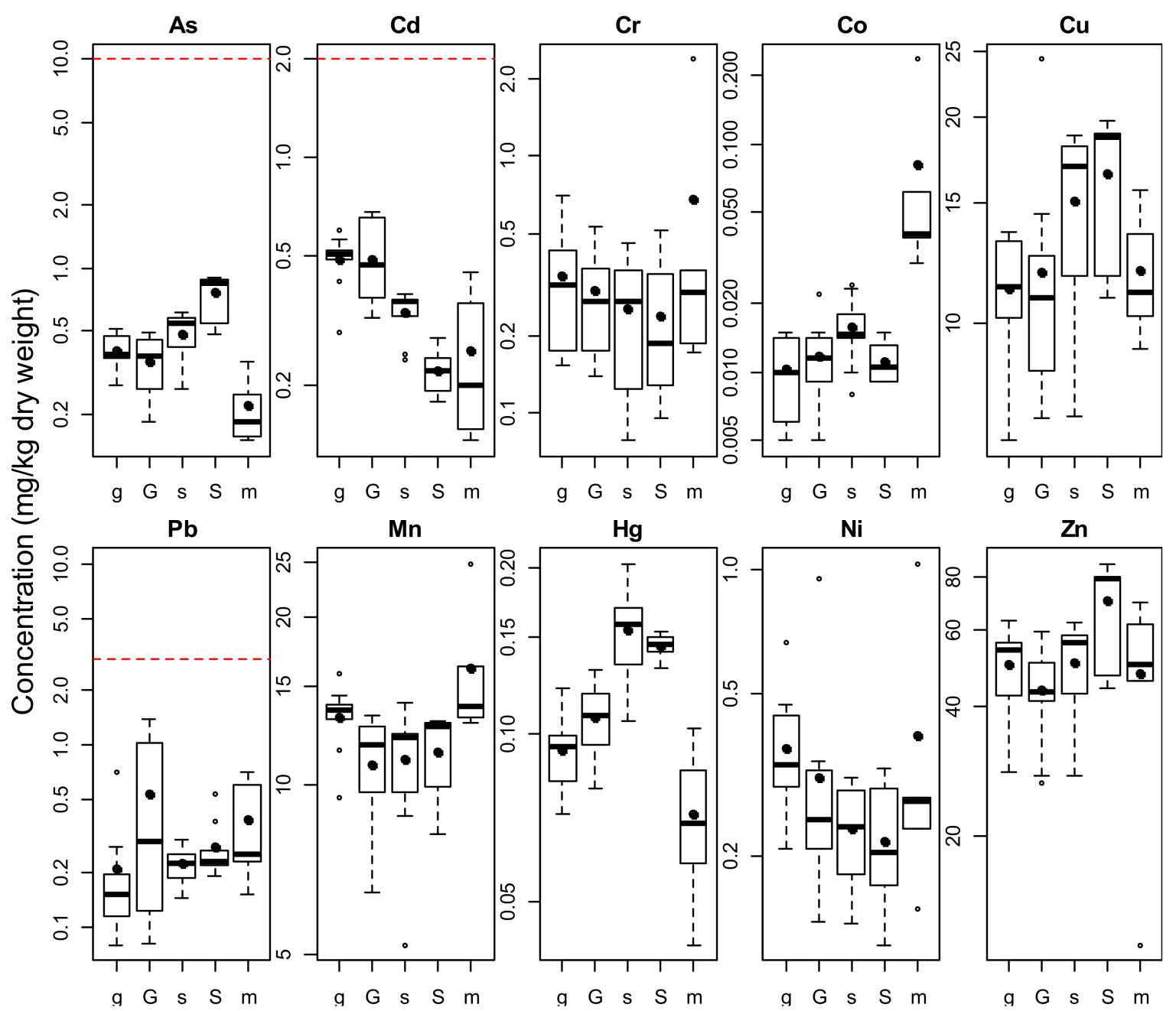

Figure 1. Boxplot for arsenic and metal concentrations of mushrooms with UK guideline values (red dashed lines). Legend: $\mathrm{S}=$ Savar $(\mathrm{HK}, n=20), \mathrm{G}=$ Gazipur $(\mathrm{HK}, n=20), \mathrm{s}=\operatorname{Savar}(\mathrm{PO} 2, n=20)$, $\mathrm{g}=$ Gazipur $(\mathrm{PO} 2, n=20), \mathrm{m}=$ market basket $(n=5)$. 
Table 1. Concentrations of elements in Pleurotus high-king $(n=40)$ and Pleurotus ostreatus $(n=40)$ mushroom samples $(\mathrm{mg} / \mathrm{kg}$, dw).

\begin{tabular}{|c|c|c|c|c|c|c|c|}
\hline \multirow{2}{*}{ Element } & \multirow{2}{*}{ Mushroom Species } & \multirow{2}{*}{ Mean \pm SD } & \multirow{2}{*}{ Median } & \multirow{2}{*}{ Range } & \multicolumn{3}{|c|}{ NIST SRM 1573a (Tomato Leaves) } \\
\hline & & & & & Certified Values & Observed Values & Recovery (\%) \\
\hline \multirow[b]{2}{*}{ As } & P. high-king & $0.56 \pm 0.25$ & 0.489 & $0.18-0.91$ & \multirow{2}{*}{$0.112 \pm 0.004$} & \multirow{2}{*}{$0.122 \pm 0.003$} & \multirow[b]{2}{*}{109} \\
\hline & P. ostreatus & $0.45 \pm 0.11$ & 0.45 & $0.263-0.62$ & & & \\
\hline \multirow{2}{*}{$\mathrm{Cd}$} & P. high-king & $0.35 \pm 0.17$ & 0.301 & $0.18-0.68$ & \multirow{2}{*}{$1.52 \pm 0.04$} & \multirow{2}{*}{$1.46 \pm 0.060$} & \multirow{2}{*}{96.1} \\
\hline & P. ostreatus & $0.41 \pm 0.10$ & 0.38 & $0.24-0.599$ & & & \\
\hline \multirow[b]{2}{*}{$\mathrm{Cr}$} & P. high-king & $0.27 \pm 0.14$ & 0.223 & $0.096-0.533$ & \multirow[b]{2}{*}{$1.99 \pm 0.06$} & \multirow[b]{2}{*}{$1.76 \pm 0.050$} & \multirow[b]{2}{*}{88.4} \\
\hline & P. ostreatus & $0.3 \pm 0.16$ & 0.313 & $0.078-0.697$ & & & \\
\hline \multirow{2}{*}{ Co } & P. high-king & $0.011 \pm 0.004$ & 0.011 & $0.005-0.022$ & \multirow{2}{*}{$0.57 \pm 0.02$} & \multirow{2}{*}{$0.61 \pm 0.040$} & \multirow{2}{*}{107} \\
\hline & P. ostreatus & $0.013 \pm 0.005$ & 0.014 & $0.005-0.024$ & & & \\
\hline \multirow{2}{*}{$\mathrm{Cu}$} & P. high-king & $14.2 \pm 4.9$ & 12.5 & $7.30-24.3$ & \multirow{2}{*}{$4.7 \pm 0.14$} & \multirow{2}{*}{$5.3 \pm 0.19$} & \multirow{2}{*}{113} \\
\hline & P. ostreatus & $13.2 \pm 3.7$ & 12.6 & $6.70-18.8$ & & & \\
\hline \multirow{2}{*}{$\mathrm{Pb}$} & P. high-king & $0.40 \pm 0.39$ & 0.23 & $0.08-1.37$ & & & \\
\hline & P. ostreatus & $0.22 \pm 0.13$ & 0.194 & $0.079-0.72$ & & & \\
\hline \multirow{2}{*}{ Mn } & P. high-king & $11.2 \pm 2.17$ & 12.2 & $6.45-13.4$ & \multirow[b]{2}{*}{$246 \pm 8$} & \multirow{2}{*}{$232 \pm 12$} & \multirow{2}{*}{94.3} \\
\hline & P. ostreatus & $12.2 \pm 2.4$ & 12.7 & $5.1-15.8$ & & & \\
\hline $\mathrm{Hg}$ & P. high-king & $0.126 \pm 0.03$ & 0.12 & $0.11-0.144$ & \multirow{2}{*}{$0.034 \pm 0.004$} & \multirow{2}{*}{$0.032 \pm 0.006$} & \multirow{2}{*}{94.1} \\
\hline Hg & P. ostreatus & $0.124 \pm 0.03$ & 0.121 & $0.094-0.154$ & & & \\
\hline & P. high-king & $0.263 \pm 0.18$ & 0.22 & $0.12-0.95$ & & & \\
\hline $\mathrm{N} 1$ & P. ostreatus & $0.3 \pm 0.12$ & 0.292 & $0.136-0.665$ & $1.59 \pm 0.07$ & $1.50 \pm 0.08$ & 94.3 \\
\hline & P. high-king & $56.9 \pm 19.5$ & 50.4 & $26.3-85.8$ & & -06 & 803 \\
\hline $\mathrm{Zn}$ & P. ostreatus & $50.2 \pm 11.3$ & 54.8 & $27.5-63.2$ & $30.9 \pm 0.7$ & \pm 0.6 & 89.3 \\
\hline
\end{tabular}

P. high-king: Pleurotus high-king, P. ostreatus: Pleurotus ostreatus. 
Table 2. Total As concentration $(\mathrm{mg} / \mathrm{kg}, \mathrm{dw})$ in cultivated mushrooms in this study and in literature (adapted and modified [30]).

\begin{tabular}{|c|c|c|c|c|c|}
\hline \multirow{2}{*}{ Element } & \multirow{2}{*}{ Study Location } & \multirow{2}{*}{ Species } & \multicolumn{2}{|c|}{ Concentration } & \multirow{2}{*}{ Reference } \\
\hline & & & Mean & Range & \\
\hline \multirow{20}{*}{ As } & \multirow{2}{*}{ Bangladesh } & P. high-king & $0.56 \pm 0.25$ & $0.18-0.91$ & \multirow{2}{*}{ This study } \\
\hline & & P. ostreatus & $0.45 \pm 0.11$ & $0.263-0.62$ & \\
\hline & Bangladesh & $\begin{array}{l}\text { P. ostreatus } \\
\text { A. bisporus } \\
\text { V. volvacea } \\
\text { G. lucidum }\end{array}$ & BDL & & [31] \\
\hline & \multirow{3}{*}{ Spain } & L. edodes & 1.393 & & \multirow{3}{*}[32,33]{} \\
\hline & & A. bisporus & 0.185 & & \\
\hline & & P. ostreatus & 0.335 & & \\
\hline & Canada & A. bisporus & $0.14 \pm 0.04$ & & [34] \\
\hline & \multirow{3}{*}{ Poland } & A. arvensis & & BDL & \multirow{3}{*}{ [35] } \\
\hline & & A. bisporus & & $0.08-0.71$ & \\
\hline & & A. Bisporus & & $0.15-1.4$ & \\
\hline & \multirow{7}{*}{ Brazil } & P. ostreatus & $0.056 \pm 0.004$ & & \multirow{7}{*}{ [36] } \\
\hline & & P. florida & $0.073 \pm 0.018$ & & \\
\hline & & P. eryngui & $0.009 \pm 0.003$ & & \\
\hline & & P. salmoneostramineus & $0.043 \pm 0.004$ & & \\
\hline & & A.sp. & $0.125 \pm 0.014$ & & \\
\hline & & A. bisporus & $0.097 \pm 0.024$ & & \\
\hline & & L. edodes & $0.210 \pm 0.009$ & & \\
\hline & \multirow{2}{*}{ Ghana } & P. ostreatus & 0.04 & & \multirow{2}{*}{ [37] } \\
\hline & & T. clypeatus & 0.1 & & \\
\hline & India & A. bisporus & $0.64 \pm 0.16$ & & [38] \\
\hline \multirow{16}{*}{$\mathrm{Cd}$} & & P. high-king & $0.35 \pm 0.17$ & $0.18-0.68$ & \multirow{2}{*}{ This study } \\
\hline & Bangladesh & P. ostreatus & $0.41 \pm 0.10$ & $0.24-0.60$ & \\
\hline & & P. ostreatus & & & \\
\hline & & A. bisporus & & & \\
\hline & Bangladesh & $V$. volvacea & BDL & & [31] \\
\hline & & G. lucidum & & & \\
\hline & & P. ostreatus & 5.39 & & \\
\hline & Mexico & A. bisporus (caps) & 0.54 & & [39] \\
\hline & & P. ostreatus & $0.074 \pm 0.002$ & & \\
\hline & & P. florida & $0.220 \pm 0.013$ & & \\
\hline & & P. eryngui & $0.011 \pm 0.003$ & & \\
\hline & Brazil & P. salmoneostramineus & $0.229 \pm 0.004$ & & [36] \\
\hline & & A.sp. & $<\mathrm{LD}$ & & \\
\hline & & A. bisporus & $<\mathrm{LD}$ & & \\
\hline & & L. edodes & $0.190 \pm 0.011$ & & \\
\hline & Australia & A. bisporus & $0.18 \pm 0.02$ & & [40] \\
\hline & Banoladesh & P. high-king & $0.27 \pm 0.14$ & $0.096-0.53$ & \\
\hline & Bangraaesn & P. ostreatus & $0.30 \pm 0.16$ & $0.078-0.70$ & This study \\
\hline & & P. ostreatus & & $0.21 \pm 0.00-0.30 \pm 0.01$ & \\
\hline & Banoladesh & A. bisporus & & $0.23 \pm 0.01-0.30 \pm 0.01$ & [31] \\
\hline$C r$ & Dangratasti & V. volvacea & $0.24 \pm 0.01$ & & {$[31]$} \\
\hline $\mathrm{Cr}$ & & G. lucidum & $0.21 \pm 0.01$ & & \\
\hline & & P. ostreatus & 63.0 & & [39] \\
\hline & Mexico & A. bisporus (caps) & 4.06 & & [39] \\
\hline & Turkey & P. sajor-caju & 8.50 & & [41] \\
\hline & & P. high-king & $0.011 \pm 0.004$ & $0.005-0.022$ & \\
\hline & Bangladesh & P. ostreatus & $0.013 \pm 0.005$ & $0.005-0.024$ & This study \\
\hline Co & Turkey & P. sajor-caju & 12.5 & & [41] \\
\hline & Australia & A. bisporus & $0.126 \pm 0.001$ & & [40] \\
\hline
\end{tabular}


Table 2. Cont

\begin{tabular}{|c|c|c|c|c|c|}
\hline \multirow{2}{*}{ Element } & \multirow{2}{*}{ Study Location } & \multirow{2}{*}{ Species } & \multicolumn{2}{|c|}{ Concentration } & \multirow{2}{*}{ Reference } \\
\hline & & & Mean & Range & \\
\hline \multirow{11}{*}{$\mathrm{Cu}$} & \multirow[t]{2}{*}{ Bangladesh } & P. high-king & $14.2 \pm 4.9$ & $7.3-24.3$ & \multirow[t]{2}{*}{ This study } \\
\hline & & P. ostreatus & $13.2 \pm 3.7$ & $6.7-18.8$ & \\
\hline & \multirow{4}{*}{ Bangladesh } & P. ostreatus & & $39.2 \pm 0.88-102.1 \pm 2.6$ & \multirow{4}{*}{ [31] } \\
\hline & & A. bisporus & & $54.6 \pm 0.86-163.4 \pm 3.9$ & \\
\hline & & V. volvacea & $101.8 \pm 2.3$ & & \\
\hline & & G. lucidum & $72.5 \pm 1.22$ & & \\
\hline & Turkey & P. sajor-caju & 10.5 & & [41] \\
\hline & \multirow{2}{*}{ Mexico } & P. ostreatus & 732 & & \multirow{2}{*}{ [39] } \\
\hline & & A. bisporus (caps) & 352 & & \\
\hline & Australia & A. bisporus & $53.4 \pm 0.251$ & & [40] \\
\hline & Hungary & A. bisporus & $58 \pm 2-65 \pm 1$ & & [42] \\
\hline \multirow{10}{*}{$\mathrm{Pb}$} & \multirow{2}{*}{ Bangladesh } & P. high-king & $0.40 \pm 0.39$ & $0.08-1.37$ & \multirow{2}{*}{ This study } \\
\hline & & P. ostreatus & $0.22 \pm 0.13$ & $0.079-0.72$ & \\
\hline & \multirow{4}{*}{ Bangladesh } & P. ostreatus & & $0.14 \pm 0.02-0.59 \pm 0.03$ & \multirow{4}{*}{ [31] } \\
\hline & & A. bisporus & & $0.15 \pm 0.01-0.22 \pm 0.02$ & \\
\hline & & V. volvacea & $0.25 \pm 0.02$ & & \\
\hline & & G. lucidum & $0.13 \pm 0.01$ & & \\
\hline & Turkey & P. sajor-caju & 27.5 & & [41] \\
\hline & \multirow{2}{*}{ Mexico } & P. ostreatus & 0.91 & & \multirow{2}{*}{ [39] } \\
\hline & & A. bisporus (caps) & 0.41 & & \\
\hline & Australia & A bisporus & $3.9 \pm 0.49$ & & [40] \\
\hline \multirow{10}{*}{ Mn } & \multirow{2}{*}{ Bangladesh } & P. high-king & $11.2 \pm 2.17$ & $6.45-13.4$ & \multirow{2}{*}{ This study } \\
\hline & & P. ostreatus & $12.2 \pm 2.4$ & $5.1-15.8$ & \\
\hline & \multirow{4}{*}{ Bangladesh } & P. ostreatus & & $52.9 \pm 1.04-104.5 \pm 1.8$ & \multirow{4}{*}{ [31] } \\
\hline & & A. bisporus & & $56.2 \pm 1.34-91.1 \pm 1.38$ & \\
\hline & & V. volvacea & $78.5 \pm 0.97$ & & \\
\hline & & G. lucidum & $64.0 \pm 0.92$ & & \\
\hline & Turkey & P. sajor-caju & 17.5 & & [41] \\
\hline & & P. ostreatus & 18.3 & & [20] \\
\hline & Mexico & A. bisporus (caps) & 9.42 & & [39] \\
\hline & Australia & A. bisporus & $10.6 \pm 0.01$ & & [40] \\
\hline & Banoladesh & P. high-king & $0.126 \pm 0.03$ & $0.11-0.14$ & This study \\
\hline & & P. ostreatus & $0.124 \pm 0.03$ & $0.094-0.15$ & \\
\hline & & P. ostreatus & $0.10 \pm 0.01$ (cap), & & \\
\hline $\mathrm{Hg}$ & & & $0.08+0.01(\mathrm{cap})$ & & [18] \\
\hline & Poland & A. bisporus & $0.05 \pm 0.01$ (stipe) & & \\
\hline & & H. erinaceus & $0.07 \pm 0.02$ (cap) & & \\
\hline & & & $0.03 \pm 0.01$ (stipe) & & \\
\hline & Banoladech & P. high-king & $0.263 \pm 0.18$ & $0.12-0.95$ & This studv \\
\hline & Bangladesh & P. ostreatus & $0.3 \pm 0.12$ & $0.136-0.665$ & I his study \\
\hline $\mathrm{Ni}$ & Turkey & P. sajor-caju & 17.5 & & [41] \\
\hline & . & P. ostreatus & 31.5 & & rogr \\
\hline & Mexico & A. bisporus (caps) & 9.02 & & [39] \\
\hline
\end{tabular}


Table 2. Cont.

\begin{tabular}{|c|c|c|c|c|c|}
\hline \multirow{2}{*}{ Element } & \multirow{2}{*}{ Study Location } & \multirow{2}{*}{ Species } & \multicolumn{2}{|c|}{ Concentration } & \multirow{2}{*}{ Reference } \\
\hline & & & Mean & Range & \\
\hline \multirow{11}{*}{$\mathrm{Zn}$} & Bancladech & P. high-king & $56.9 \pm 19.5$ & $26.3-85.8$ & \multirow{2}{*}{ This study } \\
\hline & Bangladesh & P. ostreatus & $50.2 \pm 11.3$ & $27.5-63.2$ & \\
\hline & \multirow{4}{*}{ Bangladesh } & P. ostreatus & \multirow{4}{*}{\multicolumn{2}{|c|}{$\begin{array}{l}30.1 \pm 0.19-75.5 \pm 0.54 \\
36.3 \pm 0.23-47.6 \pm 0.46\end{array}$}} & \multirow{4}{*}{ [31] } \\
\hline & & A. bisporus & & & \\
\hline & & V. volvacea & & & \\
\hline & & G. lucidum & & & \\
\hline & Turkey & P. sajor-caju & 110 & & [41] \\
\hline & \multirow{2}{*}{ Ethiopia } & P. ostreatus & $59.2 \pm 0.02$ & & \multirow{2}{*}{ [43] } \\
\hline & & P. sajor-caju & $59.2 \pm 0.03$ & & \\
\hline & Australia & A. bisporus & $43.8 \pm 0.20$ & & [40] \\
\hline & Hungary & A. bisporus & $60 \pm 0-62 \pm 0$ & & [42] \\
\hline
\end{tabular}

BDL: below detection limit (level $0.01 \mathrm{mg} / \mathrm{kg} 1 \mathrm{dw}$ ), LD: limit of detection, P: PleurotusL: Lentinula, A: Agaricus, T: Termitomyces, V: Volvariella, G: Ganoderma, H: Hericium.

\subsection{Arsenic}

Mean concentration of total As (mg/kg, dw) in Pleurotus high-king and Pleurotus ostreatus were $0.56 \pm 0.25$ and $0.45 \pm 0.11$, respectively (Tables 1 and 2). Noteworthy, however, is Pleurotus high-king, with As concentration reaching near $1.0(0.91 \mathrm{mg} / \mathrm{kg}$, dw) which could be considered low as those were below the normal level $(<1 \mathrm{mg} / \mathrm{kg}, \mathrm{dw})$ stated for mushrooms grown in uncontaminated media $[44,45]$. Amongst different cultivated mushrooms in different countries, total As concentration of this study were lower with an exception of Lentinula edodes in Spain (Table 2). However, an investigation in Bangladesh found As in mushrooms below the detection level [31]. For dry mushrooms, the UK guideline value for As is $10.0 \mathrm{mg} / \mathrm{kg}$ [46] and the As concentration in the mushroom samples both from cultivated and market basket were within the safe limit according to the guideline value (Figure 1). Furthermore, the concentration of As in mushrooms of this study were within the limit of Australia and New Zealand Food Standard Code [47], and also below the maximum allowable concentrations $(1.0 \mathrm{mg} / \mathrm{kg})$ of As recommended by the Ministry of Health of China [48].

Inorganic As (arsenate and arsenite) is classified as human carcinogen [49]. Speciation of As (arsenite, arsenate, MMA, and DMA) in selected mushroom samples $(n=9)$ was conducted and found the percentage of inorganic As species ranged from 38 to $72 \%$. This was consistent with study in which the researchers also reported that inorganic species were the major components in mushrooms [50] and ranged from 0.14 to $0.89 \mathrm{mg} / \mathrm{kg}$ of As, similar to this study. In a study in Bangladesh during 2002 scientists [6] found inorganic As species as the predominant species in rice straw which estimated arsenate, arsenite, and DMA as about $90 \%$, up to $8 \%$ and up to $4 \%$ of the total, respectively. The inorganic species are the most harmful and potentially pose a health risk to the population if those are consumed on a regular basis through foods. Additionally, DMA is a probable human carcinogen [51,52] according to the United States Environmental Protection Agency (USEPA), though less toxic than inorganic As.

\subsection{Cadmium}

The Cd concentrations of mushrooms in this study were very low (below $1.0 \mathrm{mg} / \mathrm{kg}, \mathrm{dw}$ ). However, undetectable level of $\mathrm{Cd}$ was found in mushroom in a study in Bangladesh [31]. Our results were in agreement with the study conducted in Mexico [39], Brazil [36], and Australia [40], with the only exception in Mexico [39] for P. ostreatus mushroom (Table 2). For dry mushrooms, the UK guideline [46] value for $\mathrm{Cd}$ is $2.0(\mathrm{mg} / \mathrm{kg}, \mathrm{dw})$ and the $\mathrm{Cd}$ concentrations of the mushroom samples in the current study $(0.18-0.68 \mathrm{mg} / \mathrm{kg})$ were far below the UK guideline value (Figure 1). 


\subsection{Chromium}

The $\mathrm{Cr}$ concentrations of mushrooms in this study were much less than those in a previously-published database (Table 2) on cultivated mushrooms except a study in Bangladesh [31]. The highest concentration of chromium $(63.0 \mathrm{mg} / \mathrm{kg}, \mathrm{dw}$ ) was observed in Mexico [39] in P. ostreatus mushroom and the lowest $(4.06 \mathrm{mg} / \mathrm{kg}, \mathrm{dw}$ ) was in A. bisporus in the same country (Table 2). The same cultivated mushroom (P. ostreatus) showed significantly higher content $(63.0 \mathrm{mg} / \mathrm{kg}, \mathrm{dw})$ in Mexico [39] than in Bangladesh.

\subsection{Cobalt}

The concentrations of Co in this study were similar $(0.011 \pm 0.004,0.013 \pm 0.005 \mathrm{mg} / \mathrm{kg}$, dw $)$ in both P. high-king and P. ostreatus which were about ten times lower in A. bisporus in Australia [40] and one thousand times lower than P. sajor-kaju in Turkey [41] (Table 2).

\subsection{Copper}

The concentrations of $\mathrm{Cu}$ in this study $(6.7-24.3 \mathrm{mg} / \mathrm{kg}, \mathrm{dw})$ were slightly higher than P. sajor-kaju, a cultivated mushroom of Turkey [41] but highest concentration was observed in Mexico [39]. However, P. ostreatus of another study in Bangladesh obtained higher $\mathrm{Cu}$ concentration [31] than the same one of this study. A. bisporus in Australia [40] and Hungary [42] contained about four times higher Cu than this investigation (Table 2).

\subsection{Lead}

Lead concentrations of mushrooms found in this study were $0.40 \pm 0.39$ and $0.22 \pm 0.13 \mathrm{mg} / \mathrm{kg}$ in P. high-king and P. ostreatus, respectively, which were slightly higher than another study conducted in Bangladesh [31] with four species including P. ostreatus. Cultivated P. sajor-caju of Turkey [41] showed about fifty time higher $\mathrm{Pb}$ content than our results whereas A. bisporus of Australia [40] demonstrated about ten and twenty times higher than P. high-king and P. ostreatus in our study, respectively. However, a study carried out in Mexico [39] found lower levels of $\mathrm{Pb}$ in P. ostreatus and A. bisporus. For dry mushrooms, the UK guideline value for $\mathrm{Pb}$ is $3.0 \mathrm{mg} / \mathrm{kg}[46,53]$. The $\mathrm{Pb}$ concentration in the mushroom samples was in compliance with the UK guideline value (Figure 1). The Pb concentrations in this study were much below the maximum allowable concentrations $(2 \mathrm{mg} / \mathrm{kg})$ of $\mathrm{Pb}$ recommended by the Ministry of Health of China [48].

\subsection{Manganese}

A little variation was observed in Mn concentration in cultivated mushrooms of this study, e.g., $11.2 \pm 2.17$ and $12.2 \pm 2.4 \mathrm{mg} / \mathrm{kg}$ in P. high-king and P. ostreatus, respectively (dry weight basis). The results of this study were much lower than the results in P. sajor-caju in Turkey [41], P. ostreatus in Mexico, P. ostreatus, A. bisporus, V. volvacea, G. lucidum in Bangladesh [31], and slightly higher than A. bisporus in Mexico [39] and Australia [40] (Table 2).

\subsection{Mercury}

Mercury is highly toxic element of the environment poses health risk depending on its form, concentration, duration, and method of exposure [54]. The concentration of $\mathrm{Hg}$ in the substrate is of much significance for mushroom production as a high concentration in the substrate accelerates its accumulation into the cap and stipe [18]. The $\mathrm{Hg}$ concentrations in mushrooms in this study were 0.126 and $0.124 \mathrm{mg} / \mathrm{kg}(\mathrm{dw})$ in P. high-king and P. ostreatus, respectively (Table 2,) which were much lower than that of Turkey [41] and Mexico [39] (Table 2). 


\subsection{Nickel}

The Ni concentrations of mushrooms in this study were much less $(0.12-0.95 \mathrm{mg} / \mathrm{kg})$ than those reported in the literature (Table 2). High levels of $\mathrm{Ni}(31.5 \mathrm{mg} / \mathrm{kg}, \mathrm{dw}$ ) were reported in mushrooms in Turkey [41] whereas the same species, P. ostreatus, in this study demonstrated a maximum $\mathrm{Ni}$ concentration of $0.665 \mathrm{mg} / \mathrm{kg}$.

\subsection{Zinc}

In this study the highest mean $\mathrm{Zn}$ level $(56.9 \mathrm{mg} / \mathrm{kg})$ was observed in P. high-king and the lowest $(50.2 \mathrm{mg} / \mathrm{kg}, \mathrm{dw}$ ) was in P. ostreatus. The species P. ostreatus showed a higher $\mathrm{Zn}$ concentration (59.2 mg $/ \mathrm{kg}, \mathrm{dw})$ in Ethiopia [43] and in another study in Bangladesh [31] as compared to our results. Same scenarios were also observed for P. sajor-caju of Ethiopia [43] and A. bisporus in Hungary [42] where very high differences in $\mathrm{Zn}$ concentration were obtained for the same species in different locations (Table 2).

\subsection{Concentrations of Elements in Powdered Mushrooms for Sale}

Ground mushroom samples (P. ostreatus and P. high-king) available in the market were also collected for analysis to investigate whether there is any toxicological hazard prevails for their consumption. The concentrations (range) of $\mathrm{As}, \mathrm{Cd}, \mathrm{Cr}, \mathrm{Co}, \mathrm{Cu}, \mathrm{Pb}, \mathrm{Mn}, \mathrm{Hg}, \mathrm{Ni}$, and $\mathrm{Zn}$ in mushroom samples $(n=5)$ were $0.15-0.36,0.14-0.44,0.17-2.4,0.03-0.24,9.20-15.6,0.15-0.61,12.9-24.9,0.041-0.10,0.15-1.04$, and $11.1-69.6 \mathrm{mg} / \mathrm{kg}$, respectively, which proved that mushroom powder of the market contained lower concentrations of $\mathrm{As}, \mathrm{Cd}, \mathrm{Cu}, \mathrm{Pb}, \mathrm{Hg}, \mathrm{Zn}$, and higher concentrations of $\mathrm{Cr}, \mathrm{Co}, \mathrm{Mn}$, and $\mathrm{Ni}$ compared to mushrooms directly collected from the growers in this study.

\subsection{Elemental Accumulation}

The average As, $\mathrm{Cd}, \mathrm{Cr}, \mathrm{Co}, \mathrm{Cu}, \mathrm{Pb}, \mathrm{Mn}, \mathrm{Hg}, \mathrm{Ni}$, and $\mathrm{Zn}$ concentration in the substrates (rice straw) of Savar were $0.563,2.15,2.05,0.789,6.48,2.91,1165,0.134,6.09$, and $62.1 \mathrm{mg} / \mathrm{kg}$, respectively, while the concentration of those elements in Gazipur were $0.47,0.18,1.27,0.58,8.64,2.58,1079,0.148$, 6.57 , and $58.1 \mathrm{mg} / \mathrm{kg}$, respectively.

The accumulation efficiency of elements in mushrooms from growing media was calculated using the accumulation factor, which is defined as the ratio of elemental concentration in the mushroom to that in the growth medium. Organisms are termed as metal hyper-accumulators when the accumulation factor remains above 1.0 [55] or, in another way, the species is termed as a hyper-accumulator when it contains more than 100 times higher concentrations of an element than other species growing on substrates of similar features [33]. The data in Table 3 demonstrated that element accumulation factors were more than $1 \mathrm{for} C \mathrm{C}$ and $\mathrm{Cd}$ at both sites, and greater than 1.0 for As and $\mathrm{Zn}$ at Savar, but less than 1.0 in other cases (representing exclusion). It has been observed that mushroom species are able to accumulate high amounts of some elements, e.g., $\mathrm{As}, \mathrm{Cd}, \mathrm{Pb}, \mathrm{Hg}$, and Se [56], particularly when mushrooms are collected from sites adjacent to heavy metal smelters [57], and landfills of sewage sludge emission areas [58]. Concentrations of heavy metals were also observed high in proximity to highways with high traffic [59-61] and emission areas [62]. The sampling site at Savar was close to highways, industries, and brick kilns, which might pose high emission and pollution [63], whereas the Gazipur site was far away from highway traffic and industries and surrounded by large trees and vegetation. Contamination of mushrooms grown at Gazipur might, therefore, be attributed to the substrate rather than the environment. 
Table 3. Accumulation factors of elements from substrate to mushrooms.

\begin{tabular}{cccccccccccc}
\hline Location & Mushroom & As & $\mathbf{C d}$ & $\mathbf{C r}$ & $\mathbf{C o}$ & $\mathbf{C u}$ & $\mathbf{P b}$ & $\mathbf{M n}$ & $\mathbf{H g}$ & $\mathbf{N i}$ & $\mathbf{Z n}$ \\
\hline \multirow{2}{*}{ Savar } & P. high-king & 1.35 & 1.30 & 0.132 & 0.009 & 3.28 & 0.073 & 0.008 & 1.63 & 0.058 & 1.18 \\
& P. ostreatus & 1.54 & 3.12 & 0.249 & 0.038 & 2.03 & 0.090 & 0.016 & 0.82 & 0.047 & 1.01 \\
\hline \multirow{2}{*}{ Gazipur } & P. high-king & 0.79 & 2.11 & 0.293 & 0.032 & 1.61 & 0.271 & 0.012 & 0.79 & 0.042 & 0.76 \\
& P. ostreatus & 0.98 & 2.19 & 0.378 & 0.032 & 1.42 & 0.121 & 0.013 & 0.58 & 0.05 & 0.92 \\
\hline \multirow{6}{*}{} & Mean & 1.07 & 2.19 & 0.263 & 0.028 & 2.09 & 0.139 & 0.012 & 0.956 & 0.049 & 0.97 \\
& SD & 0.51 & 1.19 & 0.189 & 0.020 & 1.13 & 0.169 & 0.006 & 0.754 & 0.020 & 0.43 \\
\hline
\end{tabular}

\subsection{Correlations between Elements in Mushrooms}

There were significant statistical correlations between elemental concentrations in mushrooms which are shown in Table 4. Significantly positive correlations were established between As and $\mathrm{Hg}$ $(p \leq 0.01), \mathrm{Hg}$ and $\mathrm{Zn}(p \leq 0.01), \mathrm{Cu}$ and $\mathrm{Hg}(p \leq 0.01), \mathrm{Pb}$ and $\mathrm{Cr}(p \leq 0.01), \mathrm{Cu}$ and $\mathrm{Mn}(p \leq 0.01)$, $\mathrm{Zn}$ and $\mathrm{Mn}(p \leq 0.01), \mathrm{Zn}$ and $\mathrm{Cu}(p \leq 0.01)$, As and $\mathrm{Cu}(p \leq 0.01)$, As and $\mathrm{Zn}(p \leq 0.01), \mathrm{Co}$ and $\mathrm{Cr}$ $(p \leq 0.01)$, As and $\mathrm{Mn}(p \leq 0.01), \mathrm{Pb}$ and $\mathrm{Co}(p \leq 0.01)$, and $\mathrm{Cd}$ and $\mathrm{Ni}(p \leq 0.01)$. The other correlations between elements were not significant. Significant negative correlations were found between $\mathrm{Cd}$ and As $(p \leq 0.01)$, and $\mathrm{Hg}$ and $\mathrm{Cd}(p \leq 0.05)$.

Table 4. Correlation coefficient matrix of elements for mushroom samples.

\begin{tabular}{|c|c|c|c|c|c|c|c|c|c|c|}
\hline & As & $\mathrm{Cd}$ & $\mathrm{Cr}$ & Co & $\mathrm{Cu}$ & $\mathbf{P b}$ & Mn & $\mathrm{Hg}$ & $\mathrm{Ni}$ & $\mathrm{Zn}$ \\
\hline As & 1.000 & & & & & & & & & \\
\hline $\mathrm{Cd}$ & -0.508 ** & 1.000 & & & & & & & & \\
\hline $\mathrm{Cr}$ & $-0.016 \mathrm{~ns}$ & $0.343 \mathrm{~ns}$ & 1.000 & & & & & & & \\
\hline Co & $-0.119 \mathrm{~ns}$ & $0.132 \mathrm{~ns}$ & $0.504^{* *}$ & 1.000 & & & & & & \\
\hline $\mathrm{Cu}$ & $0.778 * *$ & $-0.056 \mathrm{~ns}$ & $0.170 \mathrm{~ns}$ & $0.130 \mathrm{~ns}$ & 1.000 & & & & & \\
\hline $\mathrm{Pb}$ & $-0.312 \mathrm{~ns}$ & $0.351 \mathrm{~ns}$ & $0.679^{* *}$ & 0.522 ** & $-0.288 \mathrm{~ns}$ & 1.000 & & & & \\
\hline $\mathrm{Mn}$ & $0.552 * *$ & $0.177 \mathrm{~ns}$ & $0.312 \mathrm{~ns}$ & $0.234 \mathrm{~ns}$ & $0.645^{* * *}$ & $-0.004 \mathrm{~ns}$ & 1.000 & & & \\
\hline $\mathrm{Hg}$ & $0.891 * *$ & $-0.470 *$ & $-0.158 \mathrm{~ns}$ & $-0.259 \mathrm{~ns}$ & 0.666 ** & $-0.383 \mathrm{~ns}$ & $0.352 \mathrm{~ns}$ & 1.000 & & \\
\hline $\mathrm{Ni}$ & $-0.055 \mathrm{~ns}$ & $0.522 * *$ & $0.215 \mathrm{~ns}$ & $0.259 \mathrm{~ns}$ & $0.117 \mathrm{~ns}$ & $0.290 \mathrm{~ns}$ & $0.154 \mathrm{~ns}$ & $0.027 \mathrm{~ns}$ & 1.000 & \\
\hline $\mathrm{Zn}$ & 0.956 ** & $-0.322 \mathrm{~ns}$ & $0.121 \mathrm{~ns}$ & $-0.044 \mathrm{~ns}$ & $0.806^{* * *}$ & $-0.168 \mathrm{~ns}$ & 0.699 ** & $0.826^{* *}$ & $0.075 \mathrm{~ns}$ & 1.000 \\
\hline
\end{tabular}

\subsection{Correlations between Elemental Concentrations in the Medium and Mushroom}

It was noted that As concentrations in the substrate for P. high-king in Savar were $0.660 \mathrm{mg} / \mathrm{kg}$ which was significantly higher $(p<0.05)$ than that of Gazipur $(0.473 \mathrm{mg} / \mathrm{kg})$. There was effectively no correlation between the concentrations of element in the substrate with the corresponding element in the mushroom. This finding agrees with some other studies [33,64,65].

\subsection{Market Basket Study}

A comparison of analyte levels in the market basket survey with the commercial products can be obtained from Figure 1. The As level in the market basket $(0.22 \mathrm{mg} / \mathrm{kg})$ was lower $(p<0.01)$ in the levels from the mushroom farm $(0.50 \mathrm{mg} / \mathrm{kg})$. The $\mathrm{Hg}$ levels were also lower $(p<0.001)$ in the market basket than in those obtained from the mushroom farms. The Co levels were higher in the market basket $(0.081 \mathrm{mg} / \mathrm{kg})$ than in the values from the mushroom farm $(0.012 \mathrm{mg} / \mathrm{kg})$.

\subsection{Daily Consumption of As and Other Elements from Mushrooms: Health Risk Index}

Based on using weekly intake rates of mushrooms and the median concentrations (fresh weight) of elements, we have estimated the weekly total consumption of As and other elements from mushrooms for adults (Table 5). 
Table 5. Health risks assessment for As and other elements from intake of mushroom for adults.

\begin{tabular}{|c|c|c|c|c|c|c|c|c|c|c|}
\hline Element & $\begin{array}{c}\text { Weekly } \\
\text { Intake Rate } \\
\text { (Fresh wt, g) }\end{array}$ & $\begin{array}{c}\text { Median } \\
\text { Concentration } \\
\text { wt }(\mathrm{mg} / \mathrm{kg})\end{array}$ & $\begin{array}{c}\text { Weekly } \\
\text { Intake (mg) } \\
\text { of Elements }\end{array}$ & $\begin{array}{l}\text { Weekly } \\
\text { Intake of } \\
\text { Element } \\
\mathrm{mg} / \mathrm{kg} / \mathrm{bw}\end{array}$ & $\begin{array}{c}\text { Oral } \\
\text { Reference } \\
\text { Dose } \\
\mathrm{mg} / \mathrm{kg} / \text { day }\end{array}$ & $\begin{array}{c}\text { Oral } \\
\text { Reference } \\
\text { Dose } \\
\text { mg/kg/week }\end{array}$ & HRI & PTWI $\mu \mathrm{g} / \mathrm{kg}$ & $\begin{array}{c}\text { PTWI } \\
\mathrm{mg} / 45 \mathrm{~kg}\end{array}$ & $\begin{array}{c}\text { Maximum } \\
\text { Consumption } \\
\text { per Week* }(g)\end{array}$ \\
\hline As & \multirow{10}{*}{0.09} & 0.047 & 0.0042 & 0.00009 & 0.0003 & 0.0021 & 0.0448 & 15 & 0.675 & 14.4 \\
\hline $\mathrm{Cd}$ & & 0.034 & 0.0030 & 0.00007 & 0.001 & 0.007 & 0.0097 & 7 & 0.315 & 9.3 \\
\hline $\mathrm{Cr}$ & & 0.027 & 0.0024 & 0.00005 & 0.003 & 0.021 & 0.0026 & & & \\
\hline $\mathrm{Co}$ & & 0.001 & 0.0001 & 0.00000 & & & & & & \\
\hline $\mathrm{Cu}$ & & 1.250 & 0.1125 & 0.00250 & 0.04 & 0.28 & 0.0089 & & & \\
\hline $\mathrm{Pb}$ & & 0.021 & 0.0019 & 0.00004 & 0.004 & 0.028 & 0.0015 & 25 & 1.125 & 53.6 \\
\hline Mn & & 1.240 & 0.1116 & 0.00248 & 0.14 & 0.98 & 0.0025 & & & \\
\hline $\mathrm{Hg}$ & & 0.012 & 0.0011 & 0.00002 & & & & 5 & 0.225 & 18.8 \\
\hline $\mathrm{Ni}$ & & 0.026 & 0.0023 & 0.00005 & 0.02 & 0.14 & 0.0004 & & & \\
\hline $\mathrm{Zn}$ & & 5.260 & 0.4734 & 0.01052 & 0.3 & 2.1 & 0.0050 & & & \\
\hline
\end{tabular}

${ }^{*}$ Consumption rate of mushroom to reach provisional tolerable intake, $\mathrm{g} /$ week. 
The Joint FAO/WHO Expert Committee on Food Additives [66] recommends that provisional tolerable weekly intakes (PTWI) of As, $\mathrm{Cd}, \mathrm{Pb}$, and $\mathrm{Hg}$ are 15, 7, 25, and $5 \mu \mathrm{g} / \mathrm{kg} /$ week, respectively. Therefore, the weekly tolerable intakes of $\mathrm{As}, \mathrm{Cd}, \mathrm{Pb}$, and $\mathrm{Hg}$ for a person weighing $45 \mathrm{~kg}$ would be $0.675,0.315,1.125$, and $0.225 \mathrm{mg}$, respectively [67]. We note that the PTWI value for As was withdrawn in 2011.

The health risk index (HRI) was estimated based on standard methods [68]. Considering the average body weight (45 kg) of an adult Bangladeshi [69], fresh mushroom consumption $(0.09 \mathrm{~g}$ weekly) and median concentration of $\mathrm{As}, \mathrm{Cd}, \mathrm{Cr}, \mathrm{Cu}, \mathrm{Pb}, \mathrm{Mn}, \mathrm{Ni}$, and $\mathrm{Zn}$ in mushroom found in this study, then the estimated HRI for As, Cd, Cr, Cu, Pb, Mn, Ni, and $\mathrm{Zn}$ are 0.0448, 0.0097, 0.0026, 0.0089, $0.0015,0.0025,0.0004$, and 0.0050 , respectively (Table 5). All the values of HRIs based on median concentration were less than one (closer to zero), suggesting that consumption of the investigated mushrooms do not pose any health risks from As and other elements for Bangladeshi consumers.

\section{Conclusions}

The concentrations of elements varied between mushrooms and collection sites. Mushrooms alone contributed to the intake of As and other elements which were below the PTWI values due to the very low consumption of mushrooms in the diet of Bangladeshis. Moreover, the estimated daily intakes were based on the best available production and consumption data, which was meagre. Due to the low consumption rate of mushrooms, it is, therefore, important to examine other food sources, such as rice, vegetables, etc., to assess the total exposure load from main Bangladeshi foods for the pollutants. As the tolerable/permissible values of $\mathrm{As}, \mathrm{Cd}$, and $\mathrm{Pb}$ are available from UK guidelines, future work should focus on formulating the values for other metals, which will provide more clear information for risk assessment.

Author Contributions: M.H.R. and M.M.R. planned the experimental design, executed the study, drafted the manuscript; R.C. conducted the statistical analysis of the data as well as English correction; R.N. provided the funding for the experiment, checked, proof read the final draft and provided full supervision.

Acknowledgments: We are grateful to the Crawford Fund, Australia, for the financial support provided to the first author to conduct academic research at CERAR located in the University of South Australia and GCER in The University of Newcastle. We thank the Project Director, Nirod Chandra Sarker and the scientific officer, Ruhul Amin of the Mushroom Development and Extension Institute, Savar, Bangladesh, and also Shafiqul Islam, Assistant Professor, Division of Soil Science, Bangladesh Agricultural University, Mymensingh for their cooperation during sampling.

Conflicts of Interest: The authors declares that there is no conflicts of interest.

\section{References}

1. Chakrabarti, D.; Singh, S.K.; Rashid, M.H.; Rahman, M.M. Arsenic: Occurrence in groundwater. In Reference Module in Earth Systems and Environmental Sciences; Elsevier: Amsterdam, The Netharland, 2013.

2. Rahman, M.M.; Owens, G.; Naidu, R. Arsenic levels in rice grain and assessment of daily dietary intake of arsenic from rice in arsenic-contaminated regions of Bangladesh-Implications to groundwater irrigation. Environ. Geochem. Health 2009, 31, 179-187. [CrossRef] [PubMed]

3. Biswas, M.; Mandal, M. Irrigation Management for Crop Diversification in Bangladesh; University Press: Dhaka, Bangladesh, 1993.

4. Chakraborti, D.; Rahman, M.M.; Das, B.; Murrill, M.; Dey, S.; Mukherjee, S.C.; Dhar, R.K.; Biswas, B.K.; Chowdhury, U.K.; Roy, S.; et al. Status of groundwater arsenic contamination in Bangladesh: A 14-year study report. Water Res. 2010, 44, 5789-5802. [CrossRef] [PubMed]

5. Ali, M.A.; Badruzzaman, A.; Jalil, M.; Hossain, M.D.; Ahmed, M.F.; Masud, A.; Kamruzzaman, M.; Rahman, M.A. Fate of arsenic extracted with groundwater. In Fate of Arsenic in the Environment; United Nations University: Tokyo, Japan, 2003; pp. 7-20. ISBN 984-32-0507-3.

6. Abedin, M.J.; Cresser, M.S.; Meharg, A.A.; Feldmann, J.; Cotter-Howells, J. Arsenic accumulation and metabolism in rice (Oryza sativa L.). Environ. Sci. Technol. 2002, 36, 962-968. [CrossRef] [PubMed] 
7. Frisbie, S.H.; Mitchell, E.J.; Mastera, L.J.; Maynard, D.M.; Yusuf, A.Z.; Siddiq, M.Y.; Ortega, R.; Dunn, R.K.; Westerman, D.S.; Bacquart, T. Public health strategies for western Bangladesh that address arsenic, manganese, uranium, and other toxic elements in drinking water. Environ. Health Perspect. 2009, 117, 410. [CrossRef] [PubMed]

8. Blackwell, M. The Fungi: 1, 2, 3 . . 5.1 million species? Am. J. Bot. 2011, 98, 426-438. [CrossRef] [PubMed]

9. Senn-Irlet, B.; Heilmann-Clausen, J.; Genney, D.; Dahlberg, A.; Guidance for Conservation of Macrofungi in Europe. ECCF Strasbg. 2007. Available online: https://www.wsl.ch/eccf/Guidance_Fungi.pdf (accessed on 4 May 2018).

10. Manzi, P.; Aguzzi, A.; Pizzoferrato, L. Nutritional value of mushrooms widely consumed in Italy. Food Chem. 2001, 73, 321-325. [CrossRef]

11. Valverde, M.E.; Hernández-Pérez, T.; Paredes-López, O. Edible mushrooms: Improving human health and promoting quality life. Int. J. Microbiol. 2015, 2015, 376387. [CrossRef] [PubMed]

12. Diez, V.; Alvarez, A. Compositional and nutritional studies on two wild edible mushrooms from northwest Spain. Food Chem. 2001, 75, 417-422. [CrossRef]

13. Li, J.; Zhang, J.; Chen, H.; Chen, X.; Lan, J.; Liu, C. Complete mitochondrial genome of the medicinal mushroom Ganoderma lucidum. PLoS ONE 2013, 8, e72038. [CrossRef] [PubMed]

14. Alom, M.M.; Bari, M.W. Investment in mushroom cultivation at Savar Upazilla: A prospective sector for Bangladesh. ASA Univ. Rev. 2010, 4, 182-185.

15. Sánchez, C. Cultivation of Pleurotus ostreatus and other edible mushrooms. Appl. Microbiol. Biotechnol. 2010, 85, 1321-1337. [CrossRef] [PubMed]

16. Niedzielski, P.; Mleczek, M.; Siwulski, M.; Gasecka, M.; Kozak, L.; Rissmann, I.; Mikołajczak, P. Efficacy of supplementation of selected medicinal mushrooms with inorganic selenium salts. J. Environ. Sci. Health Part B 2014, 49, 929-937. [CrossRef] [PubMed]

17. Mleczek, M.; Niedzielski, P.; Siwulski, M.; Rzymski, P.; Gąsecka, M.; Goliński, P.; Kozak, L.; Kozubik, T. Importance of low substrate arsenic content in mushroom cultivation and safety of final food product. Eur. Food Res. Technol. 2016, 242, 355-362. [CrossRef]

18. Rzymski, P.; Mleczek, M.; Siwulski, M.; Gasecka, M.; Niedzielski, P. The risk of high mercury accumulation in edible mushrooms cultivated on contaminated substrates. J. Food Compos. Anal. 2016, 51, 55-60. [CrossRef]

19. Baloch, U.K. WHEAT: Post-Harvest Operations; FAO: Rome, Italy, 1999.

20. Chakma, S.; Rahman, M.; Islam, P.; Awal, M.; Roy, U.; Haq, M. Arsenic in rice and rice straw. Bangladesh Vet. 2012, 29, 1-6. [CrossRef]

21. Kalač, P.; Svoboda, L.R. A review of trace element concentrations in edible mushrooms. Food Chem. 2000, 69, 273-281. [CrossRef]

22. Barmon, B.K.; Sharmin, I.; Abbasi, P.K.; Mamun, A. Economics of mushroom (Agaricus bisporus) production in a selected Upazila of Bangladesh. Agriculturists 2012, 10, 77-89. [CrossRef]

23. Kamal, A.; Fauzia, B.; Abul, K. Mushroom production in Bangladesh: Present scenario and potentialities. SAARC J. Agric. 2009, 7, 91-105.

24. Water Content of Mushrooms. Available online: http:/ /wholefoodcatalog.info/nutrient/water/mushrooms/ (accessed on 4 May 2018).

25. Cui, Y.-J.; Zhu, Y.-G.; Zhai, R.-H.; Chen, D.-Y.; Huang, Y.-Z.; Qiu, Y.; Liang, J.-Z. Transfer of metals from soil to vegetables in an area near a smelter in Nanning, China. Environ. Int. 2004, 30, 785-791. [CrossRef] [PubMed]

26. USEPA, R.-B.C.T.; Manual, E.P.S.G. Stressor Identification Guidance Document; EPA 822-B-00-025; Office of Water and Office of Research and Development, Environmental Protection Agency: Washington, DC, USA, 2000.

27. Rahman, M.M.; Asaduzzaman, M.; Naidu, R. Consumption of arsenic and other elements from vegetables and drinking water from an arsenic-contaminated area of Bangladesh. J. Hazard. Mater. 2013, 262, 1056-1063. [CrossRef] [PubMed]

28. Team, R.C. R: A Language and Environment for Statistical Computing. 2013. Available online: https:/ / www.eea.europa.eu/data-and-maps/indicators/oxygen-consuming-substances-in-rivers / r-development-core-team-2006 (accessed on 4 May 2018). 
29. Kula, I.; Solak, M.H.; Uğurlu, M.; Işıloğlu, M.; Arslan, Y. Determination of mercury, cadmium, lead, zinc, selenium and iron by ICP-OES in mushroom samples from around thermal power plant in Muğla, Turkey. Bull. Environ. Contam. Toxicol. 2011, 87, 276-281. [CrossRef] [PubMed]

30. Falandysz, J.; Borovička, J. Macro and trace mineral constituents and radionuclides in mushrooms: Health benefits and risks. Appl. Microbiol. Biotechnol. 2013, 97, 477-501. [CrossRef] [PubMed]

31. Mohiuddin, K.; Alam, M.M.; Arefin, M.T.; Ahmed, I. Assessment of nutritional composition and heavy metal content in some edible mushroom varieties collected from different areas of Bangladesh. Asian J. Med. Biol. Res. 2016, 1, 495-501. [CrossRef]

32. Llorente-Mirandes, T.; Llorens-Munoz, M.; Funes-Collado, V.; Sahuquillo, A.; Lopez-Sanchez, J.F. Assessment of arsenic bioaccessibility in raw and cooked edible mushrooms by a PBET method. Food Chem. 2016, 194, 849-856. [CrossRef] [PubMed]

33. Braeuer, S.; Goessler, W.; Kamenik, J.; Konvalinkova, T.; Zigova, A.; Borovicka, J. Arsenic hyperaccumulation and speciation in the edible ink stain bolete (Cyanoboletus pulverulentus). Food Chem. 2018, 242, 225-231. [CrossRef] [PubMed]

34. Smitht, P.G.; Koch, I.; Reimer, K.J. Arsenic speciation analysis of cultivated white button mushrooms (Agaricus bisporus) using high-performance liquid chromatography-Inductively coupled plasma mass spectrometry, and X-ray absorption Spectroscopy. Environ. Sci. Technol. 2007, 41, 6947-6954. [CrossRef]

35. Rzymski, P.; Mleczek, M.; Siwulski, M.; Jasinska, A.; Budka, A.; Niedzielski, P.; Kalac, P.; Gasecka, M.; Budzynska, S. Multielemental analysis of fruit bodies of three cultivated commercial Agaricus species. J. Food Compos. Anal. 2017, 59, 170-178. [CrossRef]

36. Maihara, V.; Moura, P.; Catharino, M.; Castro, L.; Figueira, R. Arsenic and cadmium content in edible mushrooms from São Paulo, Brazil determined by INAA and GF AAS. J. Radioanal. Nucl. Chem. 2008, 278, 395-397. [CrossRef]

37. Quarcoo, A.; Adotey, G. Determination of heavy metals in Pleurotus ostreatus (Oyster mushroom) and Termitomyces clypeatus (Termite mushroom) sold on selected markets in Accra, Ghana. Mycosphere 2013, 4, 960-967. [CrossRef]

38. Reddy, N.M.; Reddi, U.B.E.; Reddy, B.T. Assessment of heavy metal threat in agaricus bisporus mushrooms cultivated from water hyacinth weed of Kolleru lake, Andhra pradesh-India. Int. J. Environ. Sci. 2012, 3, 28.

39. Muñoz, A.H.S.; Corona, F.G.; Wrobel, K.; Soto, G.M.; Wrobel, K. Subcellular distribution of aluminum, bismuth, cadmium, chromium, copper, iron, manganese, nickel, and lead in cultivated mushrooms (Agaricus bisporus and Pleurotus ostreatus). Biol. Trace Elem. Res. 2005, 106, 265-277. [CrossRef] [PubMed]

40. Koyyalamudi, S.R.; Jeong, S.-C.; Manavalan, S.; Vysetti, B.; Pang, G. Micronutrient mineral content of the fruiting bodies of Australian cultivated Agaricus bisporus white button mushrooms. J. Food Compos. Anal. 2013, 31, 109-114. [CrossRef]

41. Sivrikaya, H.; Bacak, L.; Saraçbaşı, A.; Eroğlu, H. Trace elements in Pleurotus sajor-caju cultivated on chemithermomechanical pulp for bio-bleaching. Food Chem. 2002, 79, 173-176. [CrossRef]

42. Vetter, J. Chemical composition of fresh and conserved Agaricus bisporus mushroom. Eur. Food Res. Technol. 2003, 217, 10-12. [CrossRef]

43. Michael, H.W.; Bultosa, G.; Pant, L.M. Nutritional contents of three edible oyster mushrooms grown on two substrates at Haramaya, Ethiopia, and sensory properties of boiled mushroom and mushroom sauce. Int. J. Food Sci. Technol. 2011, 46, 732-738. [CrossRef]

44. Kalač, P. Chemical composition and nutritional value of European species of wild growing mushrooms: A review. Food Chem. 2009, 113, 9-16. [CrossRef]

45. Kalač, P. Trace element contents in European species of wild growing edible mushrooms: A review for the period 2000-2009. Food Chem. 2010, 122, 2-15. [CrossRef]

46. Survey of Metals in a Variety of Foods. Food Survey Information Sheet. 2007. Available online: http: / / www.food.gov.UK/Science/Surveillance (accessed on 4 May 2018).

47. ANZFA (Australia New Zealand Food Authority) Food Standards Code. Standard 1.4.1. Contaminants and Natural Toxicants. 2011. Available online: https://www.legislation.gov.au/Details/F2015C00052 (accessed on 4 May 2018). 
48. China, E. Maximum Levels of Contaminants in Foods GB2762-2005. China State Environmental Protection Administration: Beijing, China, 2005. Available online: http://www.speciation.net/Database/Links/ USDA-FAIRS-Product-Specific-Maximum-Levels-of--Contaminants-in-Foods-2006-;i3429Contaminantsin-Foods-2006-;i3429 (accessed on 4 May 2018).

49. Roy, P.; Saha, A. Metabolism and toxicity of arsenic: A human carcinogen. Curr. Sci. 2002, 81, 38-45.

50. Gonzálvez, A.; Llorens, A.; Cervera, M.; Armenta, S.; de la Guardia, M. Non-chromatographic speciation of inorganic arsenic in mushrooms by hydride generation atomic fluorescence spectrometry. Food Chem. 2009, 115, 360-364. [CrossRef]

51. International Agency for Research on Cancer. A review of human carcinogens: Arsenic, metals, fibres, and dusts. IARC Monogr. Eval. Carcinog. Risks Hum. C 2012, 100, 169-211.

52. US EPA. Office of Pesticide Programs Chemicals Evaluated for Carcinogenic Potential-Annual Cancer Report; EPA: Washington DC, USA, 2016.

53. European Commission. Commission Regulation (EC) No. 466/2001; Directive 2001/22/EC; European Commission EU: Brussels, Belgium, 2001.

54. Bernhoft, R.A. Mercury toxicity and treatment: A review of the literature. J. Environ. Public Health 2012, 2012, 460508. [CrossRef] [PubMed]

55. Zhang, W.; Cai, Y.; Tu, C.; Ma, L.Q. Arsenic speciation and distribution in an arsenic hyperaccumulating plant. Sci. Total Environ. 2002, 300, 167-177. [CrossRef] [PubMed]

56. Rácz, L.; Oldal, V. Investigation of uptake processes in a soil/mushroom system by AES and AAS methods. Microchem. J. 2000, 67, 115-118. [CrossRef]

57. Kalac, P.; Niznanska, M.; Bevilaqua, D.; Staskova, I. Concentrations of mercury, copper, cadmium and lead in fruiting bodies of edible mushrooms in the vicinity of a mercury smelter and a copper smelter. Sci. Total Environ. 1996, 177, 251-258. [CrossRef]

58. Cibulka, J.; Miholova, D.; Szakova, J.; Fucikova, A.; Slamova, A.; Stehulova, I.; Barlakova, S.; Sisak, L.; Pulkrab, K. Cadmium, Lead, Mercury and Caesium Levels in Wild Mushrooms and Forest Berries from Different Localities of the Czech Republic. Sci. Agric. Bohem. 1996. Available online: http:/ /agris.fao.org/ agris-search/search.do?recordID=CZ9601339 (accessed on 4 May 2018).

59. Säumel, I.; Kotsyuk, I.; Hölscher, M.; Lenkereit, C.; Weber, F.; Kowarik, I. How healthy is urban horticulture in high traffic areas? Trace metal concentrations in vegetable crops from plantings within inner city neighbourhoods in Berlin, Germany. Environ. Pollut. 2012, 165, 124-132. [CrossRef] [PubMed]

60. Morton-Bermea, O.; Hernández-Álvarez, E.; González-Hernández, G.; Romero, F.; Lozano, R.; Beramendi-Orosco, L. Assessment of heavy metal pollution in urban topsoils from the metropolitan area of Mexico City. J. Geochem. Explor. 2009, 101, 218-224. [CrossRef]

61. Duong, T.T.; Lee, B.-K. Determining contamination level of heavy metals in road dust from busy traffic areas with different characteristics. J. Environ. Manag. 2011, 92, 554-562. [CrossRef] [PubMed]

62. Lepšová, A.; Mejstř́k, V. Accumulation of trace elements in the fruiting bodies of macrofungi in the Krušné hory mountains, Czechoslovakia. Sci. Total Environ. 1988, 76, 117-128. [CrossRef]

63. Aktaruzzaman, M.; Fakhruddin, A.; Chowdhury, M.; Fardous, Z.; Alam, M. Accumulation of heavy metals in soil and their transfer to leafy vegetables in the region of Dhaka Aricha Highway, Savar, Bangladesh. Pak. J. Biol. Sci. 2013, 16, 332-338. [PubMed]

64. Melgar, M.J.; Alonso, J.; Garcia, M.A. Total contents of arsenic and associated health risks in edible mushrooms, mushroom supplements and growth substrates from Galicia (NW Spain). Food Chem. Toxicol. 2014, 73, 44-50. [CrossRef] [PubMed]

65. Johanson, K.J.; Nikolova, I.; Taylor, A.F.; Vinichuk, M.M. Uptake of Elements by Fungi in the Forsmark Area; SKB: Orange, CA, USA, 2004; Volume 4.

66. Joint FAO/WHO Expert Committee on Food Additives (JECFA); World Health Organization. Compendium of Food Additive Specifications: Addendum 8; Food \& Agriculture Organization, 2000; Volume 52.

67. USEPA. Integrated Risk Information System; USEPA: Washington, DC, USA, 2002. 
68. Fang, Y.; Sun, X.Y.; Yang, W.J.; Ma, N.; Xin, Z.H.; Fu, J.; Liu, X.C.; Liu, M.; Mariga, A.M.; Zhu, X.F.; et al. Concentrations and health risks of lead, cadmium, arsenic, and mercury in rice and edible mushrooms in China (vol 147, pg 147, 2013). Food Chem. 2014, 151, 379. [CrossRef]

69. Yu, T.H.; Peng, Y.Y.; Lin, C.X.; Qin, J.H.; Li, H.S. Application of iron and silicon fertilizers reduces arsenic accumulation by two Ipomoea aquatica varities. J. Integr. Agric. 2016, 15, 2613-2619. [CrossRef] 